\title{
Gordon Tullock and experimental public choice
}

\author{
Arthur Schram ${ }^{1,2,3}$
}

Published online: 2 February 2016

(c) The Author(s) 2016. This article is published with open access at Springerlink.com

\begin{abstract}
In this paper, I discuss Gordon Tullock's views on Experimentation in Economics, his own research experiment, and his influence on the field of experimental public choice. I argue that Tullock can credibly claim to have been an early supporter of the method and that his work is cited more often than that of other public choice scholars active in the same period. His work on rent seeking forms the basis of an extensive experimental literature and studies on trust, demand revelation and voter turnout have been strongly influenced by Tullock's work.
\end{abstract}

Keywords Gordon Tullock · Experiments $\cdot$ Public choice

JEL Classification H00 · C99

\section{Introduction}

Gordon Tullock has been recognized as having had an important influence in the development of economics in general and of experimental public choice in particular (Houser and Stratmann 2012). His influence on research in this field can

This paper was prepared for the Tullock Memorial Conference at George Mason University, Oct 2-3, 2015.

$\triangle$ Arthur Schram

Schram@uva.nl

1 Center for Research in Experimental Economics and Political Decision Making CREED, Amsterdam School of Economics, University of Amsterdam, Amsterdam, The Netherlands

2 Robert Schumann Center for Advanced Studies, European University Institute, Florence, Italy

3 Department of Economics, European University Institute, Villa San Paolo, Via della Piazzuola 43, 50133 Florence, Italy 
easily be deduced from the grand number of studies that build on his work. This note, therefore, provides a brief overview of the subfields in experimental public choice that build on Tullock's work.

Of course, the fact that experimental research is grounded in Tullock's contributions is neither a necessary nor a sufficient condition to conclude that he embraced experimentation as a fruitful research method for economics. For this, one needs to go back and search his work for views on this matter. In this note, I also discuss the results of such a search. Hence, the aim of this note is to discuss both, Tullock's views and his influence on experimental public choice. ${ }^{1}$

For decades, Tullock yearly attended the meetings of the European Public Choice Society. I have known him since I started attending these meetings in 1985. In the early 1990s, papers using data from laboratory experiments started to appear at these meetings and since then I have had the pleasure of entertaining many lively discussions with Tullock about the experimental method. He has often expressed support for using experiments to study questions in public choice and was keen on emphasizing that he had been one of the early proponents of the method. On various occasions, Tullock would make statements like "Arthur, you're doing the right thing. I've always said that experiments are very suited to study economic phenomena. I was saying so even before Vernon Smith became famous". One of the things I will show in this note is that such statements are verifiably true.

To do so, the next section presents a selection of quotes from Tullock's extensive body of work that relate to his opinion on experiments in economics. Subsequently, I will address the question of whether experimental economists refer to Tullock's work. For this purpose, Sect. 3 provides some simple statistics. Section 4 discusses an experiment that Tullock himself organized and Sect. 5 provides a brief overview of literatures in experimental public choice that build on Tullock's work. Finally, I quote in Sect. 6 a few experimental papers that explicitly support or reject ideas developed by Tullock.

\section{What did Tullock say about experiments?}

To provide an overview of what Tullock has said over the years about experiments in economics, it is useful to move backward in time. ${ }^{2}$ However Tullock's views on experiments had developed over the decades, they cumulated in him designing and running an experiment, which he published in Tullock (1999). This experiment will be discussed in Sect. 3.

Fifteen years prior to this work, Tullock had already embarked on an experimental project. In Tideman and Tullock (1976), he and his co-author had

\footnotetext{
1 Throughout this note, I will use the term "experiment" as it is commonly understood in the economics literature. This refers to data collection in a controlled (laboratory or field) environment that is structured in a way that allows one to derive causal relations between the variables of interest. A typical experiment in economics induces values to outcomes (and pays participants accordingly) to create a true (micro)economic environment (Smith 1976).

2 Note that Vernon Smith published a first experimental paper in 1962, but that the method did not really catch on until the 1970 s.
} 
presented a new method for collecting funds for public goods that made revelation by consumers of their true valuation of the good a dominant strategy (thus avoiding the free-riding problem). This publication sparked vivid discussions, culminating in a special issue of Public Choice in 1977, dedicated to the topic. Tullock quickly saw that experiments provided a way to let data speak to these discussions. Though he and Tideman embarked on the project together, Tullock in the end was not involved in its completion. Yet, Tideman (1983) emphasizes:

“This research grew out of Gordon Tullock's suggestion that experiments with the demand-revealing process were needed" (p. 387)

In the same period, in 1979, the first of a series of yearly edited volumes called Research in Experimental Economics appeared, edited by Vernon Smith (Smith 1979). Tullock (1980a) presents a very positive review of this volume. He writes:

"I have been biased in favor of experimental work in economics and other social sciences, since I first advocated them in the Organization of Inquiry. It seems to me that this is a research tool which we have tended to ignore, and which should have received a good deal more resources than it has." (p. 253)

Tullock's claim to have advocated experiments as early as 1966 (which is when the Organization of Inquiry appeared) is substantiated by a closer look. In this book, Tullock draws analogies between research in the sciences and the social sciences. In doing so, he naturally arrives at the conclusion:

"There are numerous areas [in economics] where experiments could be run with the full knowledge of the subjects and where considerable knowledge could be obtained." (p. 139)

In his elaboration of this issue, Tullock arrives at a description of the interaction between experimentation and theory that was remarkably insightful for the time and predicted various future developments in the field of experimental economics. Consider, for example, Tullock's argument:

"Experiments, necessarily, are set up in terms of hypotheses, theories, and Weltanschauungen. If these initial intellectual presuppositions of the experiments are in a primitive condition as they were in the natural sciences several 100 years ago, then the initial experiments are likely to simply indicate difficulties in the theories being tested, but not to lead to any solution of these difficulties." (p. 139)

This nicely describes the role early experiments played in analyzing game theoretic predictions based on rational self-interested players. For example, the highly cited paper $^{3}$ by Güth et al. (1982) provided strong evidence of the problems with this standard theory but was not very insightful as to how to resolve these problems.

The Organization of Inquiry goes on to argue:

3462 citations in Google Scholar (Oct 1, 2015). 
"As time goes by, however, new theories which explain various experimental results will be developed; these in turn will be tested by experimentation. This will lead to the invention of new theories, and the eventual outcome, we can legitimately hope, will be a much clearer perception of the social reality." (p. 139)

Again, this is predictive of the development of the literature. For example, in response to the results of Güth et al., new theories of social preferences were developed (e.g. Fehr and Schmidt 1999; Bolton and Ockenfels 2000) that aimed to better predict such outcomes. These were subsequently subjected to experimental testing (e.g., Charness and Rabin 2002; Engelmann and Strobel 2004), which led to renewed theories, etc. This booming literature is an example of precisely the kind of process that Tullock described in 1966 in the quotes above.

In the same book, Tullock also showed a keen understanding of the experimental methodology. In fact, he argues for methods that since have become standard in the literature. First, in line with the above analysis of the interaction between theory and experiments, Tullock recognized the important role that experiments can have as tests of economic theories:

"We prefer to depend on theories which are subject to deduction and experimental testing rather than on those which are "verified" solely by our perception of a pattern." (p. 100)

A rough estimate shows that over $50 \%$ of the experiments published in economics test theories (Schram 2005).

Second, in experimental economics, repetition (and replication) is often argued to be one of its main advantages. Tullock foresaw this merit of the method:

“... [a general result requires that] an experiment has been repeated several times, and a given result has been obtained." (p. 92)

"The difference between observation and experiment turns on whether the investigator does or does not have control of the repetition of the reported events." (p. 123)

"These problems fortunately do not arise in the case of experiments, which can normally be repeated at will." (p. 123)

Third, in experimental economics, decision-based compensation is seen as a prerequisite for creating an environment that is informative for the discipline (cf. fn 1). In chapter VII of the Organization of Inquiry Tullock does argue in favor of financial compensation of participants in an experiment, but is only thinking of a flat hourly fee. This is one example where he did not foresee how a major methodological issue would develop. ${ }^{4} \mathrm{He}$ did, however, foresee a second major norm. In experimental economics, deception of subjects is fundamentally banned (in fact, no journal in economics would publish a paper in which participants are incorrectly informed). The reason is given in a textbook by Davis and Holt (1993):

\footnotetext{
${ }^{4}$ In fact, the development was already going on at the time. Roth (1995) argues that there was already a tendency to use performance-based incentives by the end of the 1950 s.
} 
"Most economists are very concerned about developing and maintaining a reputation among the student population for honesty in order to ensure that subject actions are motivated by the induced monetary rewards rather than by psychological reactions to suspected manipulation. Subjects may suspect deception if it is present." (p. 23)

A very similar argument was given by Tullock, 27 years earlier:

"[In psychology experiments] the explanation given the subject is frequently simply a "cover" designed to conceal the real experiment from him. Unfortunately, this fact is getting around; experimental subjects may develop a considerable degree of sophistication which will make them systematically distrust the psychological experimenter." (p. 92)

All in all, Tullock's verbal claim to be an early supporter of the field of experimental economics is corroborated by statements he made in early publications, most notably in the Organization of Inquiry (1966). Remarkably, he foresaw many of the discussions on experimental methodology that would follow in subsequent decades.

\section{Do experimentalists use Tullock's work?}

Given his early interest in experiments, a next question is whether experimentalists are interested in Tullock. A crude measure for this is the number of times Tullock's work is cited in experimental papers. First, I consider in Fig. 1 the number of papers in the leading field journal Experimental Economics ${ }^{5}$ that cite Tullock and compare this to citations to a set of other leading scholars of Public Choice. ${ }^{6}$

Figure 1 shows that these public choice scholars are rarely cited in Experimental Economics (in total, $<6 \%$ of the papers ever published there cite any of these authors). Of those cited, Tullock is second only to Kenneth Arrow in the number of times his work is cited. ${ }^{7}$ Of the seven citations, four were to the so-called Tullock (rent-seeking) contests to be discussed below.

For a more general (and even more crude) overview, Fig. 2 shows the number of hits in Google Scholar when searching for the author's name in combination with the term "laboratory experiment". Once again, Tullock is amongst the most cited public choice scholars.

All in all, it appears that experimental economists rarely cite public choice scholars, but when they do Tullock is amongst the most cited.

\footnotetext{
5 Experimental Economics published its first issue in 1998. The numbers underlying Fig. 1 were measured in September 2015, over a total of 486 papers in 64 issues of the journal.

6 The choice of "leading scholars" is admittedly arbitrary. The author made a first selection and adjusted this following comments at the Tullock Memorial Conference at GMU in October 2015.

7 It should be noted that the large majority of citations to Kenneth Arrow in the experimental literature refers to the Arrow-Pratt measure of risk aversion, which is not really public choice.
} 


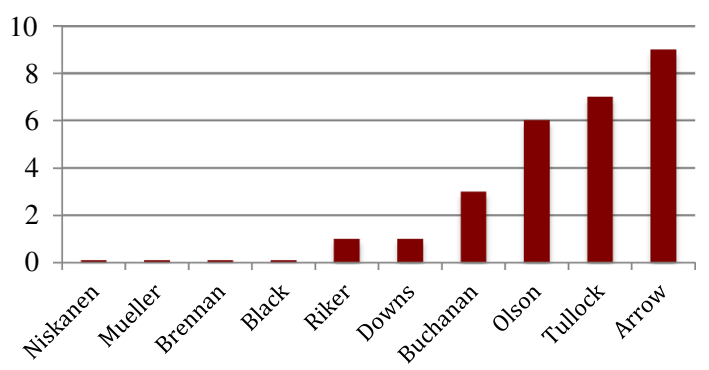

Fig. 1 Cites in Experimental Economics. Notes Bars show the number of papers in Experimental Economics that cite the author concerned. The authors considered are William Niskanen, Dennis Mueller, Geoffrey Brennan, Duncan Black, William Riker, Anthony Downs, James Buchanan, Mancur Olson, Gordon Tullock, and Kenneth Arrow

Fig. 2 Google Hits. Notes Bars show the number of hits when searching in Google Scholar (on Sept 25, 2015) for the combination "first-name lastname" and "laboratory experiment" (e.g., "Gordon Tullock" "laboratory experiment"). The authors are depicted in the note to Fig. 1

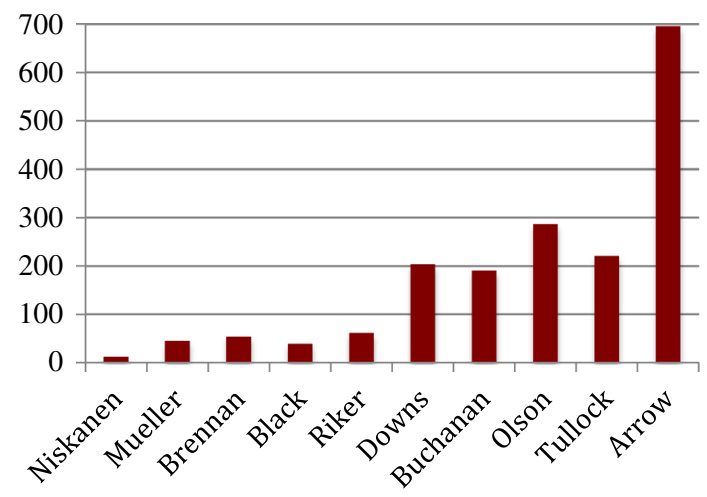

\section{Has Tullock done experiments?}

Given his early interest in experiments, it comes as no surprise that Tullock eventually designed and ran an experiment, which was published in Tullock (1999). In this experiment, subjects participate in prisoners' dilemmas (PD). This was a 'risky' endeavor because experiments on social dilemmas like the PD were already very common by that time, and much was already known about how efficient cooperation is affected by a variety of variables. It would seem hard at the time to come up with a novel insight. A much cited literature review by John Ledyard (1995) explicitly lists factors that have been shown to positively or negatively affect efficient cooperation.

Tullock was unsatisfied with this literature, in particular because he felt that the external validity of most of the games studied in these experiments was very low. In his view, the 'real world' was very different than the laboratory world typically used. In his words, most interactions outside of the laboratory "do not involve prisoners". In particular, Tullock (1999) lists three problems with the standard design: In the laboratory environment, 
(1) participants are chosen by the experimenter, while in the world outside of the laboratory, people choose their own partners to interact with;

(2) communication is usually not allowed, while communication is a crucial part of human interaction in the 'real world';

(3) pairs of participants are typically fixed whereas outside of the laboratory, people can leave partners for others if they are unsatisfied with the way things are going.

In such 'traditional' experiments substantial levels of (efficient) cooperation is typically observed in early rounds, but free-riding increases with repetition.

To address these problems, Tullock designed an experiment that deviated in three important ways from much of the prior literature. His experiment involved a group of players in a room that could form pairs, while three or four remained unpaired on the sideline. Pairs could communicate and individually decide on their strategies in a PD. This was repeated ten times. If anyone was unsatisfied with the course of events in their pair, they were free to break up and pair up with one of the sidelined participants. The results were certainly noteworthy. Of the ten pairs in this experiment, seven cooperated throughout the ten rounds. In aggregate more than $97 \%$ of the decisions were to cooperate.

This cooperation level is remarkable and serves to make the main point of the paper. It must be said, however, that on some dimensions, the experiment falls short of the state of the art in the late 1990s. First, the paper neglects some important papers that had already appeared. For example, the strong effect of communication on cooperation had already been documented in Ledyard's 1995 review. Also, the effect of endogenous partner choice had already been observed in various papers, including Orbell and Dawes (1993) and Hayashi and Yamagishi (1998). Second, the paper does not fulfill the standards set in the experimental economics literature at the time. In particular:

- it fails to develop a benchmark of the 'standard environment', to which Tullock's environment can be compared;

- compared to the standard case, there are multiple changes (partner choice, communication, and the possibility of re-pairing);

- Tullock combined data collected at two different locations (Tucson, Arizona and Arlington, Virginia) without testing for subject pool effects;

- the number of observations (10 pairs) is very low.

I strongly suspect, however, that the only goal of the paper was to make a point about the validity of the standard experiments. In that respect, it achieves what it set out to do.

\section{What experimental fields build on Tullock's work?}

There are various research areas that could be captured under the umbrella of 'experimental public choice' (Schram 2003). These include studies on the voluntary provision of public goods (including work on the tragedy of the commons); rent- 
seeking contests; trust; demand revelation; and voting (e.g. the turnout paradox and spatial voting). One could argue that Tullock has influenced each of these area's, but his impact was perhaps least for the public goods literature. For the other areas, I briefly provide an overview of Tullock's influence. ${ }^{8}$

\subsection{Rent seeking}

Rent seeking is an area where Tullock's (1967a) work founded a complete experimental field. Rent seeking refers to the situation where welfare losses occur because resources are (unproductively) used in an attempt to obtain governmentcontrolled rents. Tullock (1980b, 1998) shows how, in equilibrium, a situation can occur where the aggregate sum allocated by players exceeds the value of the rent. This so-called over-dissipation and the circumstances under which it can occur has been the topic of many experiments. Tullock's influence on this experimental rentseeking literature (which extends to studies on all-pay auctions and raffles) is wonderfully described in Houser and Stratmann (2012). In their words:

“Tullock's hypothesis regarding rent-seeking was seminal to a literature of experiments." (p. 212)

Experimental studies mostly provide support for the Nash (i.e., Tullock) prediction of over-dissipation, when the model predicts so. Moreover, as predicted by the theory, such over-dissipation decreases with the level of players' risk aversion. ${ }^{9}$

\subsection{Trust}

There is an extensive experimental literature on trust and its role in economic interactions (for seminal examples, see Fehr et al. 1993 or Berg et al. 1995). However, few experimentalists realize Tullock's (1967b) early and important contribution to the study of trust. In this short note, Tullock argues that a PD only involves trust, if it is played sequentially. This is another paper discussed extensively by Houser and Stratmann (2012). In their words:

“Tullock's early realization was exceptionally forward-looking and foreshadowed the flourishing of trust game research in experimental economics that would only begin to appear more than two decades later." (p. 212)

Indeed, the importance of trust is now well recognized, and the fact that Tullock noted this as early as 1967 is remarkable at the least. For more details, see Houser and Stratmann (2012).

\footnotetext{
8 Tullock's work also had an influence on the development of neuro-economics, a field closely related to experimental economics (Houser and Stratmann 2012).

9 For more details, see Houser and Stratmann (2012).
} 


\subsection{Demand revelation}

In 1976, Tullock and Nick Tideman published a theoretical paper in the Journal of Political Economy in which they describe a mechanism that uses Clarke taxes to create a dominant strategy of demand revelation for a public good (Tideman and Tullock 1976). This publication led to a lively academic discussion that culminated in a special issue of Public Choice (1977) -initiated by Tullock himself- dedicated to the mechanism. More details about this mechanism -which they dubbed the 'demand revealing process' - and the subsequent debate are given in Tideman's contribution to this issue.

As mentioned before, Tideman (1983) presents the results of a field experiment that started as a joint project with Tullock and intended to test the theoretical properties of the mechanism. He invited a set of college fraternities to apply the mechanism in making decisions about their fraternity. The paper reports support for the mechanism. The design allows for compensation for participation. It does not, however, induce values for the outcome of the decision making process. As a consequence, this experiment does not allow for a test of whether the demand revealing process leads to truthful revelation of preferences for the public good.

An experiment by Attiyeh et al. (2000) does allow for such a test. In this experiment, values are induced and the data allow one to compare subjects' expressed demand to their known value for the good. The results provide no support for truthful revelation. Only a small minority of the subjects reports their true value, even though doing so is a dominant strategy. Only one theoretical prediction is supported by the outcome of this experiment. This is that the Clarke taxes paid ought to decrease with increased group size. The Attiyeh et al. experiment provides evidence that this is indeed the case.

\subsection{Voter turnout}

Tullock's contribution to the literature on voter turnout is an elaboration of Anthony Down's (1957) turnout paradox. In short, this paradox confronts the high levels of voter turnout at mass elections with the observation that for most voters the expected value of the vote will be lower than the costs of casting it (due to the extremely low probability that any individual vote will be decisive for the outcome). In his Towards a Mathematics of Politics (1967c) Tullock extends this basic theory and provides arguments why people may turn out after all.

Two elements stand out in this analysis. First, Tullock introduced game-theoretic arguments into the discussion by noting that the negative expected net benefits of a vote no longer hold if they make everybody abstain. If nobody else casts a vote, any single voter is decisive for the outcome and the paradox no longer holds. Tullock rightfully notes (p. 110) that one needs to determine the theoretically predicted turnout level by determining the strategic equilibrium amongst the voters. Such an equilibrium analysis did not appear in the literature until Palfrey and Rosenthal presented their analysis of the participation game in 1983. Second, Tullock stressed the important role that information and social pressures have in the turnout decision. 
Both elements have been investigated. Such experiments typically apply the participation game in the laboratory (e.g., Großer and Schram 2006, 2010; Levine and Palfrey 2007). By and large, experimental studies show that turnout is predicted quite well by a quantal response equilibrium (McKelvey and Palfrey 1995). ${ }^{10}$ The results also show that -as predicted by Tullock-information and social pressure are important determinants of the decision to cast a vote.

\section{5 'Missing' experiments}

There are at least three areas of Tullock's research that I would have expected to yield more experimental work. The first is on external effects and collective choice. In the Calculus of Consent, Buchanan and Tullock (1962) discuss the relationship between the existence of external effects and the extent of collective decision making. A question one can address experimentally is when and why subjects choose specific collective institutions to solve problems with external effects? There is an abundant literature showing that subjects in public goods games are willing to punish (at a cost to themselves) free riders in a public good environment (e.g., Fehr and Gächter 2000). Though a recent paper (Markussen et al. 2014) analyzes the choice between formal sanction regimes and informal sanctioning, there is certainly room for much more experimental work in this area.

The same holds for Tullock's $(1969,1974)$ work on the economics of crime. Though some papers have appeared that utilize laboratory experiments to study 'criminal' activity (e.g. van Winden and Ash 2012), and in particular tax evasion (e.g., Gërxhani and Schram 2006), the Tullock approach to studying criminal activity in terms of (expected) costs and benefits provides a framework that is very suited for further experimental analysis.

Finally, Tullock is well known for analysis of logrolling, i.e., vote trading in legislatures and its effect on government spending (Tullock 1959; Buchanan and Tullock 1962). This is another environment that lends itself for experimental testing. Yet, though various experimental studies on strategic voting have appeared, I know of only two on vote trading: McKelvey and Ordeshook (1980) and a recent working paper by Casella and Palfrey (2015).

\section{Experimental results on Tullock's ideas}

In search of explicit experimental validation or rejection of Tullock's ideas, I have found only three experimental papers that explicitly relate their results to theoretical views put forward by Tullock.

First, in the previously mentioned study by Markussen et al. (2014) on formal and informal sanctioning, the authors observe that their result that participants often prefer not to install formal sanctioning coincides with Buchanan and Tullock's views:

\footnotetext{
10 The quantal response equilibrium can be interpreted as an extension of Nash equilibrium that allows for noisy decision making.
} 
"To be sure, Buchanan and Tullock wrote half a century ago that'The existence of external effects of private behavior is neither a necessary nor a sufficient condition for an activity to be placed in the realm of collective choice' (1962, p. 57).” (p. 303)

Note, however, that these authors argue that the reason for their results lies in social preferences; a view that seems hard to reconcile with Buchanan and Tollock's ideas.

Second, as mentioned above, Atitiyeh et al. (2000) found in their laboratory analysis of the demand revelation process that:

“... Tideman and Tullock's argument that, simply from the rules of the pivot mechanism, the Clarke taxes ought to fall, per capita, was supported in our experiments."

Recall, however, that the authors found very little evidence of truthful demand revelation in their data.

Third, Potters et al. (1998) conclude from their rent-seeking experiments:

"We find substantial evidence for the predictive power of the [Tullock] rentseeking model, particularly if one allows for the fact that people sometimes make mistakes or are confused about what to do." (p. 783)

This support for the model has been replicated in many experiments on rent seeking.

\section{Concluding discussion}

All of the contributions to this special issue provide evidence of the incredible width and creativity of Gordon Tullock's scholarship. His work has influenced a large variety of research programs within economics, political science, biology and law. In this note, I have tried to show his influence in the field of experimental economics.

In particular, I have tried to show that Tullock was one of the early supporters of using experimental methods to address research questions in economics. In the end, his interest in the method led to the publication of one paper where he used an experiment to make a point. His influence on the field is much more substantial than this, however.

Tullock's work has inspired experimental studies of rent seeking, trust, the demand-revelation process and voter turnout. His exceptional scholarship provides scope for many more experiments that can build on his work.

Acknowledgments I thank Roger Congleton and the other organizers of the Tullock memorial conference for the opportunity to develop and present this work and Klarita Gërxhani, Jens Großer and two anonymous reviewers for useful comments. 
Open Access This article is distributed under the terms of the Creative Commons Attribution 4.0 International License (http://creativecommons.org/licenses/by/4.0/), which permits unrestricted use, distribution, and reproduction in any medium, provided you give appropriate credit to the original author(s) and the source, provide a link to the Creative Commons license, and indicate if changes were made.

\section{References}

Attiyeh, G., Franciosi, R., \& Isaac, R. M. (2000). Experiments with the pivot process for providing public goods. Public Choice, 102, 95-114.

Berg, J., Dickhaut, J., \& McCabe, K. (1995). Trust, reciprocity, and social history. Games and Economic Behavior, 10, 122-142.

Bolton, G., \& Ockenfels, A. (2000). ERC: A theory of equity, reciprocity, and competition. The American Economic Review, 90(1), 166-193.

Buchanan, J., \& Tullock, G. (1962). The calculus of consent: Logical foundations of a constitutional democracy. Ann Arbor: University of Michigan Press.

Casella, A., \& Palfrey, T. (2015). Trading votes for votes: A decentralized matching algorithm. Working paper, Columbia University.

Charness, G., \& Rabin, M. (2002). Understanding social preferences with simple tests. The Quarterly Journal of Economics, 117(3), 817-869.

Davis, D., \& Holt, Ch. (1993). Experimental economics. Princeton: Princeton University Press.

Downs, A. (1957). An economic theory of democracy. New York: Harper and Row.

Engelmann, D., \& Strobel, M. (2004). Inequality aversion, efficiency, and maximin preferences in simple distribution experiments. The American Economic Review, 94(4), 857-869.

Fehr, E., \& Gächter, S. (2000). Cooperation and punishment in public goods experiments. The American Economic Review, 90(4), 980-994.

Fehr, E., Kirchsteiger, G., \& Riedl, A. (1993). Does fairness prevent market clearing? An experimental investigation. The Quarterly Journal of Economics, 108(2), 437-459.

Fehr, E., \& Schmidt, K. (1999). A theory of fairness, competition, and cooperation. Quarterly Journal of Economics, 114(3), 817-868.

Gërxhani, K., \& Schram, A. (2006). Tax evasion and income source: A compara-tive experimental study. Journal of Economic Psychology, 27(3), 402-422.

Großer, J., \& Schram, A. (2006). Neighborhood information exchange and voter participation: An experimental study. American Political Science Review, 100(2), 235-248.

Großer, J., \& Schram, A. (2010). Public opinion polls, voter turnout and welfare: An experimental study. American Journal of Political Science, 54, 700-717.

Guth, W., Schmittberger, R., \& Schwarze, B. (1982). An experimental analysis of ultimatum bargaining. Journal of Economic Behavior and Organization, 3, 367-388.

Hayashi, N., \& Yamagishi, T. (1998). Selective play: Choosing partners in an uncertain world. Personality and Social Psychology Review, 2, 276-289.

Houser, D., \& Stratmann, Th. (2012). Gordon Tullock and experimental economics. Public Choice, 152(1), 211-222.

Ledyard, J. (1995). Public goods: A survey of experimental research. In J. Kagel \& A. Roth (Eds.), The handbook of experimental economics (pp. 111-194). Princeton: Princeton University Press.

Levine, D., \& Palfrey, Th. (2007). The paradox of voter participation? a laboratory Study. American Political Science Review, 101(1), 143-158.

Markussen, Th, Putterman, L., \& Tyran, J.-R. (2014). Self-organization for collective action: An experimental study of voting on sanction regimes. The Review of Economic Studies, 81(1), 301-324.

McKelvey, R., \& Ordeshook, P. (1980). Vote trading: An experimental study. Public Choice, 35(2), 151-184.

McKelvey, R., \& Palfrey, Th. (1995). Quantal response equilibria for normal form games. Games and Economic Behavior, 10, 6-38.

Orbell, John M., \& Dawes, Robyn M. (1993). Social welfare, cooperators' advantage, and the option of not playing the game. American Sociological Review, 58(6), 787-800. 
Palfrey, Th, \& Rosenthal, H. (1983). A strategic calculus of voting. Public Choice, 41, 7-53.

Potters, J., de Vries, C., \& van Winden, F. (1998). An experimental examination of rational rent-seeking. European Journal of Political Economy, 14(4), 783-800.

Roth, A. E. (1995). Introduction to Experimental Economics. In J. H. Kagel \& A. E. Roth (Eds.), Handbook of experimental economics (pp. 3-109). Princeton: Princeton University Press.

Schram, A. (2003). Experimental public choice. In C. Rowley \& F. Schneider (Eds.), Encyclopedia of Public Choice, (pp. 96-104). Dordrecht: Kluwer Academic Publishers. Revised version appeared in 2008.

Schram, A. (2005). Artificiality: The tension between internal and external validity in economic experiments. Journal of Economic Methodology, 12(2), 225-238.

Smith, V. (1962). An experimental study of competitive market behavior. Journal of Political Economy, 70(2), 111-137.

Smith, V. (1976). Experimental economics: Induced value theory. American Economic Review Papers and Proceedings, 66(2), 274-279.

Smith, V. (Ed.). (1979). Research in experimental economics. Greenwich: JAI Press Inc.

Tideman, N. (1983). An experiment in the demand revealing process. Public Choice, 41, 387-401.

Tideman, N., \& Tullock, G. (1976). A new and superior process for making social choices. Journal of Political Economy, 84(6), 1145-1159.

Tullock, G. (1959). Some problems with majority voting. Journal of Political Economy, 67, 571-579.

Tullock, G. (1966). The Organization of Inquiry. Durham, NC: Duke University Press. Page numbers based on online version at http://oll.libertyfund.org/titles/1555.

Tullock, G. (1967a). The welfare costs of tariffs, monopolies and theft. Western Economic Journal, 5, 224-232.

Tullock, G. (1967b). The prisoner's dilemma and mutual trust. Ethics, 77, 229-230.

Tullock, G. (1967c). Toward a mathematics of politics. Ann Arbor: University of Michigan Press.

Tullock, G. (1969). An economic approach to crime. Social Science Quarterly, 50(1), 59-71.

Tullock, G. (1974). Does punishment deter crime? The Public Interest, 14, 103-111.

Tullock, G. (1980a). Book review of "Research in Experimental Economics" (Vol. 1 by V. Smith (Ed.), JAI Press Inc., Greenwich, 1979); Public Choice, 35(2), 253.

Tullock, G. (1980b). Efficient rent seeking. In J. Buchanan, J. Tollison, \& G. Tullock (Eds.), Toward a theory of the rent-seeking society (pp. 153-179). College Station: Texas A\&M University Press.

Tullock, G. (1998). The fundamentals of rent-seeking. In A. Owens \& C. Rowley (Eds.), The lock luminary 1(2).

Tullock, G. (1999). Non-prisoner's dilemma. Journal of Economic Behavior and Organization, 29, 455-458.

van Winden, F., \& Ash, E. (2012). On The behavioral economics of crime. Review of Law and Economics, 8, 181-213. 